\title{
FURTHER CHARACTERIZATION OF THE PROTEINS OF BOAR SEMINAL PLASMA BY ISOELECTRIC FOCUSING ON POLYACRYLAMIDE
}

\author{
U. LAVON,* J. C. BOURSNELL AND P. A. BRIGGS \\ A.R.C. Unit of Reproductive Physiology and Biochemistry, \\ Cambridge $\dagger$
}

(Received 27th Fanuary 1972, accepted 3rd Februrary 1972)

In an earlier study on the characteristics of boar seminal plasma (Boursnell, Nelson \& Cole, 1966), use was made of ultrafiltrates, though this did not include an investigation of the ultrafiltered proteins. Recently, preliminary determinations have shown that the ultrafiltrate contains $4 \%$ of the seminal plasma protein and is devoid of the haemagglutinating protein $\mathrm{H}$ (Boursnell \& Briggs, 1969).

In a further study of the nature of this protein material, isoelectric focusing on polyacrylamide plates was used. Comparisons of this material were made with whole seminal plasma, seminal plasma from which the haemagglutinin was absorbed with washed bull spermatozoa (Boursnell, 1967) and with proteins 'A Seph' and 'A Dial' prepared from boar seminal plasma as described by Boursnell et al. (1966). 'A Seph' should contain the haemagglutinin and 'A Dial' should lack it (Boursnell \& Briggs, 1969).

Seminal plasma was collected by artificial vagina from boars housed at the Animal Research Station. Pooled samples of 'A Seph' and 'A Dial' were dialysed against water, freeze-dried and dissolved in water to give a protein concentration suitable for isoelectric focusing.

The apparatus used for the ultrafiltration of seminal plasma was a smaller version of Jesting's (1964) method as modified by Boursnell et al. (1966). This utilized 8/32 Visking cellophane tubing (Scientific Instrument Centre, London) which did not require a mesh support and a single knot sufficed at the end of the tubing. An 8-cm length of tubing gave a flow rate of about $2.5 \mathrm{ml} / \mathrm{hr}$. Evaporation of the ultrafiltered fluid was negligible. Boar seminal plasma was absorbed four times with bull spermatozoa, as described by Boursnell (1967). Isoelectric focusing of the various samples was performed according to the technique of Lavon \& Boursnell (1971).

Using these preparations, a number of new facts were revealed about the electrophoretic pattern of seminal plasma proteins (Plate 1).

It is clear that the haemagglutinating protein $\mathrm{H}$, which was shown to be present in PI. 1, Figs. 1, 5 and 6, is revealed as an extra band at the most alkaline end of the plate. This is in agreement with the high isoelectric point (pH 9.4) found in previous studies for this protein (Boursnell \& Briggs, 1969).

* Present address: 1 Goor Street, Rehovot, Israel

† Postal address: Animal Research Station, 307 Huntingdon Road, Cambridge CB3 0JQ. 
It is also clear from this plate that the protein which was designated by Lavon \& Boursnell (1971) in the seminal plasma and vesicular secretion as No. 1, is in fact a mixture of two proteins of which one is the haemagglutinin. This protein is absent in Pl. 1, Figs. 2, 3 and 4.

The presence of the haemagglutinin appears to cause a 'trailing' of stainable protein which is more intense in the seminal plasma and the 'A Seph' than in the other samples. This 'trailing' was shown in an earlier attempt to demonstrate the position of the haemagglutinin by immersing the plate in a $1 \%$ saline suspension of washed sheep red cells. A trail of adhering red cells covered the whole length of the electrophoretic pattern where haemagglutinin was present (seminal plasma and vesicular secretion) but not where it was absent (epididymal plasma).

As was shown by Lavon \& Boursnell (1971), protein B as 'B Dial' is precipitated at the site of sample application by the water system employed in the isoelectric focusing. It can be seen that this happens to a lesser extent with seminal plasma from which the majority of the haemagglutinin has been absorbed. This fact suggests that it is difficult to absorb out all the haemagglutinin from seminal plasma even with bull spermatozoa.

Nelson \& Boursnell (1966) noted that boar epididymal plasma combines with and inhibits the haemagglutinin. They also showed that this protein can combine with a number of acidic proteins and that the resulting precipitates exhibit haemagglutinating activity as was found with many preparations of protein B obtained from 'B Dial'.

A likely explanation of these phenomena is that a competition for haemagglutinin exists between the acidic proteins in boar seminal plasma and bull spermatozoa. For this reason, although 'free' haemagglutinin cannot be demonstrated, failure to remove all the haemagglutinin held in combination would most likely result in the protein complex precipitating in situ under the low ionic strength conditions prevailing in the electrophoresis. It is suggested that the passage of the current may slowly break up these complexes, resulting in the trailing observed.

It should be mentioned that, by absorbing boar seminal plasma with bull spermatozoa, a number of proteins which do not originate in the seminal plasma appear on the plate (PI. 1, Fig. 2). The source of these proteins may be either from residues of bull seminal plasma trapped between the spermatozoa, or from the spermatozoa themselves.

The identity of the ultrafiltrate protein and protein A (as defined by Boursnell \& Briggs, 1969) is fairly certain, although it is not possible to detect all 'A Dial' and 'A Seph' proteins in the ultrafiltrate pattern. Differences also exist between the 'A Seph' and the 'A Dial' proteins in addition to the absence of the haemagglutinin in the latter. It is interesting that protein A leaks only partially through the Visking cellophane sac on pressure ultrafiltration, as is obvious from the protein pattern of the remaining sac contents (PI. 1, Fig. 6). By contrast, this protein appears to be largely retained by pressure dialysis in spite of the very high suction pressures developed by the plaster of Paris blocks which were used for concentrating protein solutions (Boursnell, Cole \& Briggs, 1968). 


\section{PLATE 1}
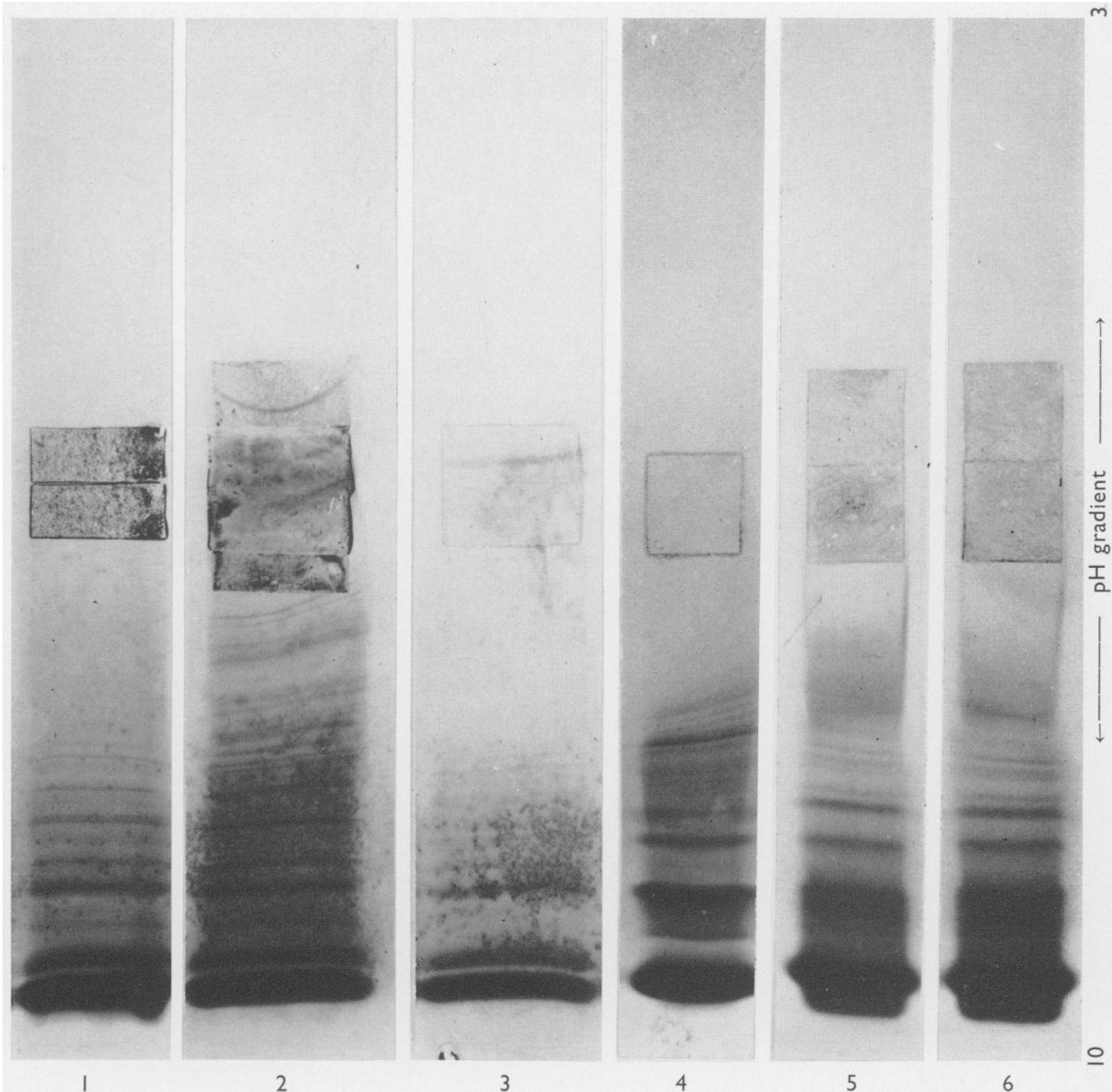

Isoclectric focusing patterns of: (1) seminal plasma (F 21/1/1970) $(0 \cdot 1 \mathrm{ml}),(2)$ the same seminal plasma $(0.15 \mathrm{ml})$ absorbed with bull spermatozoa, (3) ultrafiltrate $(0.15 \mathrm{ml})$ from the same seminal plasma concentrated $7 \cdot 5$ times by compression between plaster of Paris blocks, (4) 'A Dial' $(0.055 \mathrm{ml})$, (5) 'A Seph' (0.08 ml), (6) 'A Seph' which was retained inside the Visking sac following pressure ultrafiltration $(0.08 \mathrm{ml})$. Figures 1 to 3 and 4 to 6 were separated on different plates and the photographs were combined. 
We are greatly indebted to $\mathrm{Mr} \mathrm{P}$. Miles for constructing the apparatus used in the electrophoresis experiments and to Mr R. Patman for photography of the stained plates and are grateful to Mr I. Wilmut and Mr J. Doggett for frequent collections of semen. We also wish to thank Mrs O. West for her skilful assistance in carrying out the ultrafiltrations.

One of the authors (U.L.) wishes to express his gratitude to the Royal College of Veterinary Surgeons Trust Fund in London for awarding him the MLC/RCVS Senior Fellowship in Animal Health for the period 1970-72 which enabled him to carry out this research.

\section{REFERENCES}

Boursnell, J. G. (1967) Boar seminal haemagglutinin. II. Combination with red cells and spermatozoa. 7. Reprod. Fert. 13, 297.

BouRsNell, J. C. \& BRIGGs, P. A. (1969) Boar seminal plasma proteins. II. Electrophoretic identification of the haemagglutinin. F. Reprod. Fert. 19, 157.

Boursneli, J. G., Cole, D. M. \& Briggs, P. A. (1968) Boar seminal plasma proteins. Further observations on the haemagglutinating protein and on the coagulation by heat of some seminal plasma proteins. F. Reprod. Fert. 17, 533.

Boursnell, J. C., Nelson, M. \& Cole, D. M. (1966) Studies on boar seminal plasma proteins. III. Fractionation by gel filtration, ion exchange and other means. Biochim. biophys. Acta, 117, 134.

Jesting, E. (1964) A method for concentration of biological fluids in large quantities. F. Lipid Res. 5, 135.

LAVon, U. \& Boursnell, J. C. (1971) Characterization of boar seminal plasma, vesicular secretion and epididymal plasma proteins by gel disc electrophoresis and isoelectric focusing on polyacrylamide. F. Reprod. Fert. 27, 227.

Nelson, M. \& Boursnell, J. C. (1966) Studies on boar seminal plasma proteins. IV. Isolation of factors with haemagglutinating and protein-precipitating activity. Biochim. biophys. Acta, 117, 144. 